\title{
Determinants of Brand Equity of QMobile: A Case Study of Pakistan
}

\author{
Arshian Aslam Sharif* $\quad$ Syed Waqar Bukhari ${ }^{\dagger}$
}

\begin{abstract}
The purpose of this paper is to examine the determinants of brand equity of QMobile users. A random survey was taken using a systematic sampling of colleges and universities in a metropolitan city, Karachi, Pakistan. The questionnaire was used to collect data. The impact of each determinant was explored by using factor analysis and multiple regression analysis. The results suggested that all the determinants have a significant impact on brand equity whereas brand response has no impact on brand equity dimension.
\end{abstract}

Keywords: Brand equity, brand loyalty, brand image, QMobile

\section{Introduction}

QMobile is a local mobile brand that was successfully launched in the Pakistani market where numerous mobile companies were already investing. The brand of QMobile started few years back with the commitment to cater each class of Pakistani market through their excellent quality cell phones. The distinctive feature of $\mathrm{Q}$ phones is that it is the only Pakistani brand in mobile phones market that has made a strong place in the minds of customers within a very short span of time. Today, QMobile ranks itself as the second largest mobile phone brand in Pakistan that has positioned itself drastically in the minds of customers.

The purpose of this study is to find out various determinants affecting the brand equity of QMobile in Pakistan (Karachi). The variables used are perceived quality, brand image, brand loyalty, brand strength and brand responses (emotional and rational responses). The idea of brand equity was developed around three decades back, when people were working and exploring things in the field of marketing. A lot of work has been done on brand equity since then.(Cobb, Tong, \& Hawley, 1995)

Another classification of branding is business to business branding. Normally companies do not focus on branding for the products operating in B to B pattern as they think that in B to B marketing, personal relations and good communication matter rather than promoting the business through official brands (Baumgarth \& Binckebanck, 2011). Hence, B to B brand equity is developed through people and their good

*Research Associate, IQRA University Karachi, Pakistan.

${ }^{\dagger}$ Business Graduate, IQRA University, Karachi, Pakistan

$\ddagger$ The aurthor would like to thank Mr. Tehseen Jawaid and the two reviewers of the journals for their comments on an earlier version of this paper. All remaining error are the author's 
human relations. People who actually perform the tasks in B to B branding are the sales people. They convince the buyers, develop good relations with them through their good communication skills and motivate them to purchase. B to B branding is not focused on by some organizations as they believe that in this business, buyers buy products rationally and so promoting the goods emotionally through brands does not work.(Rosenbroijer, 2001)But in today's competitive environment, business branding should not be ignored.

Many researchers have explained the concept of brand equity in numerous ways using various variables. The concept of brand equity is a usual concept when it comes to be explored conduct a study or research on this marketing term. Whether we talk about goods or services, all the studies done in the past on brand equity show that the better a brand's equity is, the more are the chances of profit in a business. Factors that affect brand equity the most are; perceived quality, brand image, brand awareness and association and brand loyalty. Apart from this, many studies have also declared the two common variables, brand awareness and brand association as two different variables; however, in past they were considered to be the same concepts of awareness and association (Ahmad \& Butt, 2012).

Despite the enormous amount of work done on brand equity in different sectors, many gaps are still left to be covered as the concept of brand equity is very broad. It is the brand equity of QMobile through which they have been able to progress rapidly in past few years and have became the mainstream brand of mobile phone market in Pakistan's telecom sector. The purpose of this study is to find out various determinants affecting the brand equity of QMobile in Pakistan (Karachi) on which no research has been conducted yet.

The direct beneficiaries of this study would be the policy makers and marketing managers of QMobile itself as they would be able to see through this particular research how various factors impact the brand equity of QMobile and then they can work accordingly to further improve their brand. The decision makers operating in QMobile can easily see how people's reaction towards, their demands and customers' perceptions of their brand.

Apart from QMobile, this study can also benefit the other local and global brands operating in mobile industry of Pakistan like Nokia, Samsung, Sony, HTC, iPhone, Megagate and Voice etc. So the impact of various variables over brand equity can work for improvement and betterment of the brand. Such studies save time, money and energy of people sitting in an industry and guide them to utilize their resources in correct dimensions. Apart from the industrialists and marketing managers, this paper can also be helpful for other researchers and students.

QMobile has successfully introduced itself in Pakistani market through continuous innovation and diverse technology. Along with this, QMobile has also created robust brand equity in the market through which they have been progressing swiftly since 2011 and became one of the massive brand of mobile phone market in Pakistan telecom sector. The purpose of this study is to find out the brand equity of QMobile in Pakistan (Karachi) on which no research has been conducted until now. So this study will help marketing manager of QMobile to identify various factors of brand equity of QMobile. 
The rest of the study is organized as follows. Section 2 analyses the experiential literature on the determinants of brand equity of QMobile in Pakistan. Section 3 represents the modeling framework for examination of the determinants. Section 4 represents the estimation results of factor analysis and multiple regression analysis. Final section concludes the study and provides some policy implementations and recommendation regarding determinants of brand equity of QMobile in Pakistan.

\section{Review of Literature}

Many studies have been conducted in the past on brand equity. Following are some of the studies included in this paper.

Lassar, Mittal, and Sharma (1995) examined the brand equity of television monitor (Sony, RCA and Goldstar) and three watches (Seiko, Bullova and Timex) by using 113 questionnaires. The variables were brand performance, social image, value and trustworthiness. The results showed that consumers demonstrate a halo across dimensions of brand equity. This suggests that if consumers evaluate a brand to perform well, consumers also expect the brand to have high levels of value, or be more trustworthy.

Pappu, Quester, and Cooksey (2000) aimed at identifying brand equity's determinants in Australian TV and car market. Structural equation modeling (SEM)and confirmatory factor analysis have been used as the statistical techniques for the study with the sample size of 539 respondents. The variables used were perceived quality, brand awareness, brand loyalty and brand association. All the variables showed significant positive results for brand equity supporting the Aaker's model of brand equity. The recommendation was to consider brand association and awareness as two different variables as they are taken as one variable by some researchers. Work upon all the four used variables is recommended to be done in order to enhance brand equity.

Pappu and Quester (2006) aimed to establish the relation between customer satisfaction and brand equity in the retail market of Australia using 601 questionnaires. Multivariate analysis of variance and confirmatory factor analysis were applied while retailer associations, retailer loyalty, retailer awareness and retailer perceived quality were the components of brand equity used in the research. Positive correlation was found for all the variables used for brand equity. It is shown through the results that in case of department store, all four used variables vary depending on customer satisfaction. However, in specialty stores, retailer perceived quality, retailer associations quality and retailer awareness vary depending upon the customer satisfaction that the retailer maintains with the buyer. The researchers recommended that better brand equity can only be developed by satisfying the customers in accordance with their different needs.

Yasin, Noor, and Mohammad (2007) aimed to find how country-of-origin image affects brand equity. The study was conducted in Malaysian electrical appliances (household) using a sample of 501 customers. The statistical techniques applied were

factor and regression analysis while the variables were brand awareness/associations, brand distinctiveness and brand loyalty. It is shown through the results that country 
of origin and image of a brand exerts positive and significant impact over brand equity. They recommended working upon country of origin image and brand loyalty so that equity can be improved timely and can be well maintained.

Jung and Sung (2008) seek to examine that how brand equity changes with the change in culture. Responses were collected from 300 participants and they were South Koreans living in Korea and America along with Americans residing in USA. Multivariate analysis of variance was used as the statistical technique and perceived quality, brand loyalty and brand association or awareness were used as the variables of the study. The results were found to be interesting. They concluded that the brand equity is affected more significantly and positively in Americans comparatively than the other two nations. Brand loyalty was found to have the greatest impact over brand equity. It was suggested that apart from the different determinants of brand equity, target market should also be kept in mind when the managers tend to maximize the brand equity.

Tong and Hawley (2009) investigated brand equity's components in Chinese sports wear market. The study was conducted using a sample of 304 participants. Confirmatory factor analysis and structural equation modeling were the statistical techniques that were used. Brand association, brand loyalty, brand awareness and perceived quality were the used variables for this research. Brand loyalty and brand association showed direct significant effect over brand equity. On the other hand, perceived quality and brand awareness did not show any significant direct impact over brand equity. The researchers suggested considering all the variables to make brand equity better, but brand loyalty and awareness should be emphasized more.

Rios and Riquelme (2010) examined to identify the variables that give impact over brand equity. Furthermore, the purpose of this study was to see the way various marketing activities enhance brand equity of the companies operating online in Australia. The sample size taken for the study was 318. SEM and factor analysis techniques were used. Value and trust association, brand loyalty and awareness were the variables of this study. Apart from brand value association, all the remaining variables showed positive effect on brand equity. It was suggested to follow the findings and work accordingly.

Pike, Bianchi, Kerr, and Patti (2010) identified that how various factors influence brand equity in Australian tourism industry taking response from 845 customers. SEM and confirmatory factor analysis techniques were used. Brand salience, brand loyalty, perceived quality and brand image were the four variables taken in this study. The results surprisingly showed that all of the four variables do not affect brand equity positively and significantly. It was suggested that marketing managers should keep a check on all the variables that affect brand equity and managers should also keep a check and maintain brand equity timely.

Mourad, Ennew, and Kortam (2011) tend to identify the variables affecting brand equity in the field of higher education. The study was conducted in Egypt taking a sample size of 600 students. Factor analysis and multiple regression techniques were applied in this study and the variables included were consumer- specific attributes, brand awareness and image. It was revealed through the findings that brand equity does not get affected by consumer specific attributes. However, brand image showed 
more significant positive effect over brand equity than brand awareness. It was suggested to follow the findings and work accordingly.

Pinar, Girard, and Eser (2012) seek to identify how the brand equity in Turkish banking industry is affected by various components. They took a sample of 607 participants and they used the statistical technique of ANOVA was used for this study. Perceived quality, brand and organizational association, brand image, loyalty and awareness were the variables used by the researchers. It was revealed through the findings that perceived quality, brand loyalty, image and association were higher in private banks. For state banks, organizational association was the highest affecting variable of brand equity while brand equity proved to be the lowest in foreign banks. It was suggested to work on all the used variables in this study in order to make brand equity better in banking sector.

Wang and Li (2012) seek to identify how the brand equity is affected in the mobile industry. The research was conducted in Taiwan in which 497 customers were part of the sample. Factor analysis and SEM (structural equation modeling) were used to execute this study. Perceived quality, perceived enjoyment, brand loyalty, brand awareness and association, usability, personalization, identifiability and purchase intention were the different variables used in this study. The brand equity was found to be affected positively and significantly by all the variables. They suggested following the findings and working accordingly.

Das, Datta, and Guin (2012) found that how a retailer's personality influences the brand equity for the retail brands in a department. The study was executed in India taking a sample of 355 customers. SEM was used as the statistical technique. Some new and different sort of variables used for this study included dependability, empathy, sophistication, vibrancy and authenticity. The findings were surprising, that is brand equity was found to have no impact from vibrancy and authenticity, however, the variables of empathy and dependability showed positive significant effect over the brand equity. They suggested follow the findings and working accordingly.

Many researches have conducted research on the topic of determinant of brand equity; some new and different kind of variables used for those studies included brand loyalty, brand awareness and association, personality, purchase intention, perceived quality, brand image, brand organization and many more. Most of the variables have a positive and significant impact on the brand equity, so the results indicate that all the above mentioned variables are very crucial for determining the brand equity.

\section{Methodology}

Research is defined as a method of finding the answers of different queries in a systematic way using the information found through various sources. Through research, one cannot only find a problem's solution but the study can also have a better understanding of the proposed idea (Neuman, 1997). When the research is focused then there are mainly two types of research approaches namely quantitative and qualitative approach. This study is following the quantitative approach of research in which relationships of various hypotheses are tested with the help of different statistical techniques. The 
quantitative approach is also called hypothetic-deductive approach in which a theory is tested (Sarangi, 2010). It has many applications in a variety of fields. An example in relation to quantitative research is to find out the factors that affect the brand equity of Nike in Pakistan. The quantitative research is also related to another classification of research, explanatory research that is discussed as follows.

The purpose of this research is explanatory in which cause and effect of variables are checked using the statistical techniques. Other kinds of research purpose are descriptive and explanatory research. This study is following the correlational design of research that describes what sort of relationship exists among the variables. The correlation among the variables could be positive and negative both. Positive correlation indicates that the variables are directly proportional to each other; however, negative correlation indicates that the variables are inversely proportional to each other.

The correlation design is used to check the relation between two or more than two variables (Lucy, 1996). Purposive sampling is done by collecting Primary data. Questionnaires using Likert scale were used to collect the data of 290 respondents of QMobile. The statistical techniques used to execute the results of this research were Regression and Factor Analysis. Firstly, Factor Analysis was applied which is a data reduction technique. The data collected through different questionnaires was passed through the process of Factor Analysis in which all attributes of any data consisting of similar properties are reduced to one factor. Next, the technique of regression analysis is used for this research, which is a dependence technique. It explains the change, which occurs in a dependent variable due to some change in one or multiple independent variables.

The regression having multiple independent variables is called multiple regression analysis. Both the techniques of factor and regression analysis have many uses in numerous fields like marketing, physical science, psychology etc (Neuman, 1997). The research model for this study is as follows:

$$
B E=\alpha_{0}+\beta_{1}(P Q)+\beta_{2}(B L)+\beta_{3}(B R)+\beta_{4}(B S)+\beta_{5}(B I)+\epsilon
$$

Where, $B E$ represents Brand Equity, $P Q$ represents Perceived Quality, $B L$ represents Brand Loyalty, $B R$ represents Response, $B S$ represents Brand Strength and $B I$ represents Brand Image.

Hypothesis of the study is constructed as follows:

- H01 = Perceived Quality has an insignificant impact on Brand Equity of QMoible.

- $\mathrm{H} 02$ = Brand Loyalty has an insignificant impact on Brand Equity of QMoible.

- H03 = Brand Response has an insignificant impact on Brand Equity of QMoible.

- H04 = Brand Strength has an insignificant impact on Brand Equity of QMoible.

- $\mathrm{H} 05$ = Brand Image has an insignificant impact on Brand Equity of QMoible. 


\section{Data Analysis}

The outcomes of different test like Reliability, Factor and Regression Analysis are discussed in this section.

Table 1: Reliability Statistics

\begin{tabular}{l|cc}
\hline Variable & Items & Cronbach Alpha \\
\hline Brand Equity (BE) & 5 & 0.855 \\
Perceived Quality (PQ) & 3 & 0.851 \\
Brand Loyalty (BL) & 4 & 0.797 \\
Brand Response (BR) & 4 & 0.710 \\
Brand Strength (BS) & 3 & 0.724 \\
Brand Image (BI) & 3 & 0.694 \\
Overall & 22 & 0.907 \\
\hline
\end{tabular}

Reliability is a test that tells us the consistency of the instrument used to gather the data. A questionnaire based on Likert Scale has been adapted to gather the responses from different people. There were total 22 different questions in that questionnaire that were chosen to be applied over regression analysis. The questionnaire comprised of 6 variables out of which 5 were independent and 1 was the dependent variable.

The reliability test was conducted in which the value represented by Cronbach Alpha expresses the reliability of the instrument used. The value of Cronbach Alpha should be equal to or greater than 0.700 (Morgan, Leech, \& Gloeckner, 2004) for the instrument in to provide enough support for internal consistency reliability. The higher the value of Cronbach Alpha, the higher is the reliability of the instrument. In case of the questionnaire used in this study, individual reliability of all the variables is greater than 0.700 in the above table except brand strength which has the value 0.694 . This alpha is marginal in terms of acceptability as a measure of reliability because it is slightly less than 0.700 . The overall reliability is 0.907 which is an excellent sign.

The sufficiency or adequacy of the sample taken in factor analysis is shown through Kaiser-Meyer-Olkin (KMO) test. The value of KMO value must be greater than 0.700 so that the sample size and items are sufficient enough to run any test (Leech, Morgan, \& Barrett, 2005) and its significance value should be less than 0.050. For this study, the KMO value is showing 0.905 which is very good and also significant by 0.000 .

Table 2 represents the factors that were made as a result of applying factor analysis. Outliers were also removed during factor analysis and all the coefficient of factor loading is greater than 0.500 . 
Table 2: Factor Loading

\begin{tabular}{|c|c|c|c|c|c|c|}
\hline \multirow{2}{*}{ Variables } & \multicolumn{6}{|c|}{ Rotated Component Matrix } \\
\hline & 1 & 2 & 3 & 4 & 5 & 6 \\
\hline BE1 & 0.675 & & & & & \\
\hline BE2 & 0.835 & & & & & \\
\hline BE3 & 0.841 & & & & & \\
\hline BE4 & 0.784 & & & & & \\
\hline BE5 & 0.872 & & & & & \\
\hline BL1 & & 0.580 & & & & \\
\hline BL2 & & 0.549 & & & & \\
\hline BL3 & & 0.852 & & & & \\
\hline BL4 & & 0.821 & & & & \\
\hline BR1 & & & 0.548 & & & \\
\hline BR2 & & & 0.722 & & & \\
\hline BR3 & & & 0.872 & & & \\
\hline BR4 & & & 0.815 & & & \\
\hline PQ1 & & & & 0.802 & & \\
\hline PQ2 & & & & 0.754 & & \\
\hline PQ3 & & & & 0.733 & & \\
\hline BS1 & & & & & 0.588 & \\
\hline BS2 & & & & & 0.787 & \\
\hline BS3 & & & & & 0.719 & \\
\hline BI1 & & & & & & 0.779 \\
\hline BI2 & & & & & & 0.733 \\
\hline BI3 & & & & & & 0.515 \\
\hline
\end{tabular}

Table 3: Regression Coefficient (Brand Equity)

\begin{tabular}{l|rrrr}
\hline \multicolumn{1}{c|}{ Model } & Coefficient & t- Statistic & P- Value & VIF \\
\hline (Constant) & 0.050 & 0.774 & 0.439 & - \\
$\mathrm{PQ}$ & 0.092 & 2.847 & 0.004 & 1.859 \\
$\mathrm{BL}$ & 0.175 & 6.929 & 0.000 & 1.656 \\
$\mathrm{BR}$ & -0.080 & -1.227 & 0.222 & 1.908 \\
$\mathrm{BS}$ & 0.059 & 1.734 & 0.084 & 2.144 \\
$\mathrm{BI}$ & 0.111 & 1.798 & 0.073 & 1.620 \\
\hline \multicolumn{4}{|c}{ Adjusted $\mathrm{R}^{2}=0.38$} & F-Statistics 37.129 \\
\end{tabular}

The Regression Table is showing the Beta values in the first column expressing the relation of each independent variable with the dependent variable. Negative Beta value indicates that the relation between and independent and dependent variable is inversely proportional. Here all the independent variables have positive relation with the dependent variable of brand equity except brand response. Only the relation between brand response and brand equity is showing negative relation which is acceptable because in case of negative or bad response (emotional or rational response) from QMobile customers the brand equity will be minimized. The higher the negative response, the lower will be the brand equity and vice versa. Next, the t value is representing the relative importance for each variable used in this study. The t-value is required to be greater than and equal to 1.68. In this study, the t-values of perceived quality, brand loyalty, brand image and brand strength are greater than 1.68 but for the remaining one variable of brand response it is less than 1.68 as shown in table 3 Next, the table is showing the $\mathrm{p}$ value that should be less than 0.1 . The p-value shows 
the significance of variables. Like the $t$ values in this research, the p-values are also less than 0.1 for all variables except brand response. The last column of table 3 is showing the VIF i.e. multi collinearity. Multi collinearity means that the dependent variable is affected by independent variables and also the independent variables affect each other. The VIF value needs to be less than 10 for zero multi collinearity. In this study as we can see none of the variables are showing multi collinearity.

The regression table also shows the Adjusted R Square that tells the variance percentage in dependent variable explained by independent variables. Here the value of Adjusted R Square is 0.38 representing that $38 \%$ of the variance in brand equity is explained by perceived quality, brand loyalty, brand image, brand strength and brand response.

The results shown in table 3 are indicating that perceived quality, brand loyalty, brand strength and brand image give positive significant impact on brand equity which means the higher the brand loyalty, perceived quality, brand strength and image, the higher would be the brand equity of QMobile in Pakistan, however, brand response do not leave any significant impact or its contribution to enhance the brand equity of QMobile in Pakistan is not significantly important. Brand response also has negative impact over the brand equity of QMobile in Pakistan as a customer's response could also be negative, leading towards negative brand equity.

\section{Conclusion and Managerial Implications}

This study was executed to find out the determinants of brand equity of QMobile in Pakistan (Karachi). The data was gathered through a questionnaire in which Likert Scale was used to measure the responses of the customers who fall between 16 to 60 years of age. Questions used in the studies of past researchers were adopted in the questionnaire used for this study. The questionnaire also proved to be reliable with $90 \%$ of reliability. Factor and regression analysis were also conducted. The last test applied to this study was regression analysis that is conducted to see how each independent variable affects the dependent variable. It was seen through regression analysis that perceived quality, brand loyalty, brand strength and brand image have positive significant impact on brand equity showing that the higher the values of these independent variables, the higher would be the brand equity of QMobile in Pakistan. But brand response gave negative insignificant effect over the brand equity which means that the higher the negative response from QMobile customers the lower will be its brand equity.

On the completion of this study and after seeing the results of factor and regression analysis, following suggestions are made in order to improve the brand equity of QMobile in Pakistan. These suggestions could be beneficial for the managers and marketers operating in mobile industry of Pakistan. This study can also benefit many researchers in future.

Constant efforts to further improve and maintain the quality of QMobile in Pakistan should be made. The mobile phones of this organization should have consistency in their quality so that they always meet their customers' expectations. As brand image has also proven to be an important element to improve the brand equity, so 
the company should continue to have strong differentiation among QMobile and other mobile phones in Pakistan. A strong and positive image should be developed in the minds of mobile phone customers. The company should continue to develop unique attributes of QMobile in order to build strong brand strength. QMobile should also initiate brand loyalty programs to achieve positive response and loyalty from all the customers. They should also now put more focus on brand building through advertising and other marketing programs to compete with other global/international brands in the market.

\section{References}

Ahmad, S., \& Butt, M. M. (2012). Can after sale service generate brand equity? Marketing intelligence and planning, 30(3), 307-323.

Baumgarth, C., \& Binckebanck, L. (2011). Sales force impact on b-to-b brand equity:conceptual framework and empirical test. Journal of Product and Brand Management, 20(6), 487-498.

Cobb, W., Tong, X., \& Hawley, J. M. (1995). Measuring customer-based brand equity: empirical evidence from the sportswear market in china. Journal of Product and Brand Management, 3(4), 262-271.

Das, G., Datta, B., \& Guin, K. K. (2012). Impact of retailer personality on consumer-based retailer equity: An empirical study of retail brands. Asia Pacific Journal of Marketing and Logistics, 24(4), 619-639.

Jung, J., \& Sung, E. (2008). Consumer-based brand equity: Comparisons among americans and south koreans in the usa and south koreans in korea. Journal of Fashion Marketing and Management, 12(1), 24-35.

Lassar, W., Mittal, B., \& Sharma, A. (1995). Measuring customer-based brand equity. Journal of Consumer Marketing, 12(4), 11-19.

Leech, N. L., Morgan, G. A., \& Barrett, K. (2005). Spss for intermediate statistics use and interpretation (2nd ed.).

Lucy, T. (1996). Does image of country-of-origin matter to brand equity. Journal of Product and Brand Management, 4(1), 48-68.

Morgan, G. A., Leech, N. L., \& Gloeckner, G. W. (2004). Spss for introductory statistics use and interpretation (2nd ed.).

Mourad, M., Ennew, C., \& Kortam, W. (2011). Brand equity in higher education. Marketing Intelligence and Planning, 29(4), 403-420.

Neuman, W. (1997). Brand equity of machinery appliances in industrial sector. International Journal of Industrial Marketing, 1(4), 345-359.

Pappu, R., \& Quester, P. G. (2006). Does customer satisfaction lead to improved brand equity? an empirical examination of two categories of retail brands. Journal of Product and Brand Management, 15(1), 4-14.

Pappu, R., Quester, P. G., \& Cooksey, R. W. (2000). Consumer-based brand equity: improving the measurement - empirical evidence. Journal of Product and Brand Management, $14(3), 143-154$. 
Pike, S., Bianchi, C., Kerr, G., \& Patti, C. (2010). Consumer-based brand equity for australia as a long-haul tourism destination in an emerging market. International Marketing Review, 27(4), 434-449.

Pinar, M., Girard, T., \& Eser, Z. (2012). Consumer-based brand equity in banking industry: A comparison of local and global banks in turkey. International Journal of Bank Marketing, 30(5), 359-375.

Rios, R., \& Riquelme, H. (2010). Sources of brand equity for online companies. Journal of Research in Interactive Marketing, 4(3), 214-240.

Rosenbroijer, R. (2001). Brand equity of electric appliances in industrial sector. International Journal of Industrial Marketing, 5(4), 345-359.

Sarangi, P. (2010). Significant components of service brand equity in healthcaresector. International Journal of Healthcare Quality Assurance, 23(4), 743-758.

Tong, X., \& Hawley, J. M. (2009). Measuring customer-based brand equity: empirical evidence from the sportswear market in china. Journal of Product and Brand Management, 18(4), 262-271.

Wang, W., \& Li, H. (2012). Factors influencing mobile services adoption: a brand-equity perspective. Internet Research, 22(2), 142-179.

Yasin, N. M., Noor, M. N., \& Mohammad, O. (2007). Does image of countryof-origin matter to brand equity? Journal of Product and Brand Management, 16(1), 38-48. 


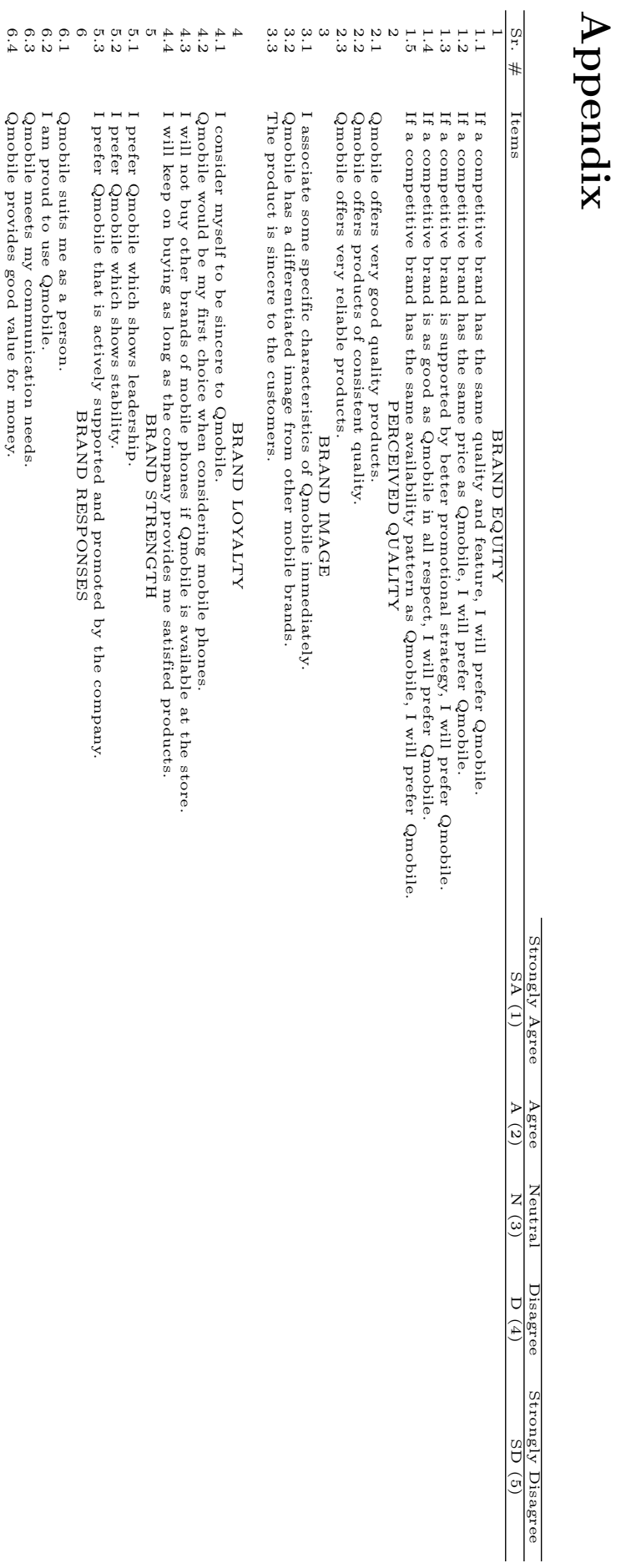

